DOI: $10.12775 / \mathrm{MBS} .2014 .004$

Medical and Biological Sciences, 2014, 28/1, 23-28

\author{
ORIGINAL ARTICLE / PRACA ORYGINALNA
}

Andrzej Lewandowski ${ }^{1}$, Maria Skowron ${ }^{1}$, Jacek Lewandowski ${ }^{2}$, Zuzanna Piekorz ${ }^{3}$, Monika Ciesielska ${ }^{4}$

\title{
SPORTS ACTIVITY OF PEOPLE WITH DISABILITIES AS RECOGNIZED BY PHYSIOTHERAPY STUDENTS
}

\author{
AKTYWNOŚĆ SPORTOWA OSÓB Z NIEPEŁNOSPRAWNOŚCIĄ \\ W ŚWIADOMOŚCI STUDENTÓW FIZJOTERAPII
}

\author{
${ }^{1}$ Department of Basis of Physical Education, Foculty of Health Sciences \\ Head: dr Andrzej Lewandowski
}

\author{
${ }^{2}$ Cathedral Rehabilitation oh the Locomotor System University School of Physical Education, Poznań \\ Head: prof. dr hab. Bogusław Marecki \\ ${ }^{3}$ Chair and Department of Kinezytherapy and Medical Massage \\ Head: dr Irena Bułatowicz \\ ${ }^{4}$ University Hospital No. 1. Anthony Jurasza in Bydgoszcz
}

Sum mary

Introduction: The role of rehabilitation therapists in treating people with disabilities undertaking sports activity should be significant. However, their training is realized by colleges providing various profiles of specialization education, which could result in inconsistent preparation of graduates in this field. The aim of this paper was to evaluate how aware physiotherapy students from different colleges are of sports and physical activity of people with disabilities as well as to establish students' attitude towards the role of sport in rehabilitation process and the direction of its development. A hypothesis was posed concerning inconsistent attitudes, awareness and knowledge in student groups from various colleges as far as taking advantage of sport in rehabilitation process was concerned. Moreover, it was assumed that those indicators would to a greater extent predispose students from colleges of physical education.

Materials and Methods: The study was conducted in 2011 and it included 134 female and male students graduating from Collegium Medicum in Bydgoszcz and the Academy of Physical Education in Poznań. The method of diagnostic poll (questionnaire) was used. Studied groups realized different curricula as far as adaptive motor activity and sports activity of people with disabilities is concerned. Collected data was differentiated according to sex and type of college of subjects; the significance of differences of multipartite variables was evaluated by Chi-squared test.
Results: Similar sex, age and basic environmental conditions structure was observed in studied groups, as well as minor differences in views and attitudes in the studied male and female groups in Bydgoszcz. Differences in the studied indicators in groups from both colleges were established only concerning the evaluation of the possibility of sports competition among athletes without or with disabilities. It was ascertained that students from a medical college associated sports activity of people with disabilities with the Foundation of Active Rehabilitation, while students from the physical education college in Poznań associated it with the Polish Sport Association of People with Disabilities "Start".

Conclusions: This study allows a conclusion that the awareness and knowledge of physiotherapy students concerning the place of sport and motor activity in the rehabilitation process are shaped to a similar extent in colleges with different profiles of specialization education, therefore, self-identification of the college candidates and a calling for this profession are significant factors in this process. 


\section{Streszczenie}

Wstęp: Rola rehabilitantów w podejmowaniu aktywności sportowej przez osoby niepełnosprawne powinna być znacząca. Ich kształcenie realizują jednak uczelnie o różnych profilach kierunkowego kształcenia, co może powodować nierówne przygotowanie absolwentów w tym zakresie. Celem pracy uczyniono ocenę świadomości studentów kierunku fizjoterapii z różnych uczelni, w zakresie sportu i aktywności fizycznej osób niepełnosprawnych oraz poznanie postaw studentów wobec roli sportu w procesie rehabilitacji, a także kierunków jego rozwoju. Postawiono hipotezę o nierównych postawach, świadomości i wiedzy, grup studenckich $\mathrm{z}$ różnych uczelni, na temat wykorzystywania sportu w procesie rehabilitacji oraz założono, że wyznaczniki te $\mathrm{w}$ większym stopniu będą predysponowały młodzież studiującą w uczelni wychowania fizycznego.

Materiał i metody: Badania zrealizowano w 2011 roku obejmując nimi młodzież kończącą studia fizjoterapii w Collegium Medicum w Bydgoszczy i Akademii Wychowania Fizycznego w Poznaniu. Zastosowano metodę sondażu diagnostycznego wykorzystując technikę ankietową, co pozwoliło na zbadanie 134 studentów i studentek. Badane zespoły realizowały różniące się programy dydaktyczne $\mathrm{z}$ zakresu aktywności ruchowej adaptacyjnej i sportu osób niepełnosprawnych. Zebrany materiał zróżnicowano płcią badanych osób i rodzajem uczelni, a do oceny istotności różnic zmiennych wielodzielnych zastosowano test Chi-kwadrat.

Wyniki badań: Zaobserwowano podobną strukturę płci, wieku i podstawowych uwarunkowań środowiskowych badanych grup młodzieży oraz niewielkie różnice w poglądach i postawach grup młodzieży męskiej i żeńskiej $\mathrm{z}$ uczelni bydgoskiej. Różnice badanych wyznaczników zespołów młodzieży obu uczelni stwierdzono jedynie w ocenie możliwości rywalizacji sportowej sportowców sprawnych i niepełnosprawnych. Ustalono, że młodzież z uczelni medycznej aktywność sportową osób niepełnosprawnych łączy z działalnością Fundacji Aktywnej Rehabilitacji, a młodzież poznańskiej uczelni wychowania fizycznego $\mathrm{z}$ Polskim Związkiem Sportu Osób Niepełnosprawnych „Start”. Wnioski: Zrealizowane badania pozwalają wnioskować, że świadomość oraz wiedza studentów fizjoterapii o miejscu sportu i aktywności ruchowej w procesie rehabilitacyjnym są $\mathrm{w}$ podobnym stopniu kształtowane $\mathrm{w}$ uczelniach o różnych profilach kierunkowego kształcenia, a tym samym samoidentyfikacja kandydatów do studiów oraz powołanie do zawodu są istotnym elementem $\mathrm{w}$ tym procesie.

Key words: sport of people with disabilities, a medical college, a physical education college, male students, female students, profession, views.

Stowa kluczowe: sport niepełnosprawnych, uczelnia medyczna, uczelnia wychowania fizycznego, studenci, studentki, zawód, poglądy.

\section{INTRODUCTION:}

Civilization development, which is an indicator of progress and prosperity of societies, alongside the effects of warfare, is one of the causes of the increase in number of accidents and consequently, the increase in number of people with disabilities. Among the majority of people, a quite common conviction is that for a person with disability, treatment, accommodation, disability pension and a job should be provided, as these would solve the problem of rehabilitation [1]. In order for a person with disability to find his or her place in society, sport proves effective. With its help along with motor activity, integrative areas such as colleague, local, national or international groups can be developed [2].

Sir Ludwig Guttmann, when ordering an increased motor activity to people with disabilities, believed that "sport should be an effective tool of personal development, regaining contact with the outside world and facilitating their integration with the community of fully able citizens" [3]. Similar views are expressed by numerous groups having great authority as far as disability and rehabilitation are concerned $[1,3,4,5,6,7,8]$, which, despite progressing professionalization of sport of people with disabilities, attests to its role and significance in the complex process of rehabilitation. It seems that the role of rehabilitation therapists in sports activity being undertaken by people with disabilities should be significant. However, their education is realized by colleges of different profiles of specialization, which could cause inconsistent preparation of graduates in this field.

The aim of this study was to evaluate awareness of physiotherapy students, differentiated by their college specialization profile, to sport and physical activity of people with disabilities. A further aim was to recognize students' attitudes towards the role of sport in the rehabilitation process and directions of its development, as well as to evaluate knowledge concerning undertaking sports-recreational activity according to the patients' needs.

A hypothesis was posed concerning inconsistent attitudes, awareness and knowledge in student groups from colleges with different profiles of specialization, in respect to the possibilities of taking advantage of sport in the rehabilitation process. Moreover, it was assumed that those indicators would to a greater extent predispose students of a physical education college.

\section{MATERIALS AND METHODS:}

The study was conducted in the first half of 2011 and included physiotherapy students graduating from full-time or part-time master's course in Ludwik Rydygier Collegium Medicum in Bydgoszcz and Eugeniusz Piasecki Academy of Physical Education in Poznań.

Method of diagnostic poll (questionnaire) was used $[9,10]$, which allowed testing 21 male and 49 female students in Bydgoszcz and 15 male and 49 female students in Poznań. Mean age for both groups was similar $(+25)$. Therefore, subjects are groups of young adults, among whom only two students from college in Bydgoszcz had disability certificates. However, according to them it did not interfere with them participating in physiotherapy program. Studied groups differed as far as the size of their home environment was concerned. Almost half of students from Bydgoszcz (42.86\%) came from larger cities of population from 100,000, and a significant percentage (35.71\%) came from smaller cities and 
towns. Half of students from Poznań lived in smaller cities, while somewhat more students came from cities of population above 100,000 (27.27\%) than from village environments $(+21 \%)$. As part of their education, studied groups realized different curricula concerning adaptive motor activity and sport of people with disabilities. Range of such classes in Bydgoszcz was 120 hours, while in Poznań it was 273 hours. Differences occurred also in class subjects and means of their realization. Students from Collegium Medicum in Bydgoszcz realized homogenous for all program of adaptive motor activity, while for sport activity of people with disability they became acquainted with the specifics of the majority of disciplines included in it. Students from the college in Poznań could select two from five areas of adaptive motor activity and three sport disciplines for people with disabilities.

Author's questionnaire included 21 closed questions, nine of which allowed gathering information about the surveyed person, while the remaining ones concerned conditions of people with disabilities undertaking physical and sports activity, and the link with rehabilitation, as well as students' preparation to future work in this profession. In order to construct this survey generally accepted rules for realizing poll studies were used [11].

Obtained data was differentiated according to sex and the type of college, and evaluation of significance of differences in multipartite variables was conducted with use of Chi-squared test, establishing the level of significance at 0.05 [12].

\section{RESULTS:}

Obtained material differentiated by sex of subjects, with the exception of two determinants concerning students from Bydgoszcz, did not vary among male and female students from colleges included in the study. It allowed merging of characteristics of men and women and settling them as representatives for the general population of subjects from the medical school in Bydgoszcz and the physical education college in Poznań.

Despite different profiles of colleges included in the study, which could lead to a different attitude of their students towards sport, the information obtained pointed to a similar commitment to realizing this area of physical activity. Almost a half $( \pm 45 \%)$ declared regular sports activity, fifth practiced a particular sport discipline or never practiced any sport, while active athletes constituted a greater percentage of students from the medical school than from the college of physical education $(8.6 \%$ and $4.7 \%)$. A definite majority of subjects $( \pm 85 \%)$ pointed to classes realized at their college as their only experience with sport of people with disabilities. A tenth of students from Bydgoszcz extended it to volunteer work, and students from Poznań to other actions including coaching $(3.6 \%)$.

Similar determinants of sport experience and personal sport activity were reflected in subjects' self-evaluation of physical fitness. More than a half described it as good $( \pm 53 \%)$, while the remaining similar percentages of subjects from both colleges described it as very good or average. As the main reasons for selecting physiotherapy as specialization, students from both colleges named the possibility to work with people $( \pm 60 \%)$ and the will to help them $( \pm 55 \%)$. Significantly lower percentage $( \pm 15 \%)$ were concerned with the prestige of the profession and experiencing illness in family or close surroundings, while the lowest percentage pointed to financial reasons or other. For the majority of subjects an expected place of employment is a private practice $( \pm 60 \%)$ or a hospital $(38.6 \%$ and $25.5 \%)$, while for several percent it is a massage or a cosmetic studio and sanatoria. Only one tenth of the subjects from both colleges believe their future professional activity to be connected with recreational activity and sport of both healthy people and those with disabilities.

Previous experience and knowledge gathered during their studies allowed the subjects to express their opinion concerning physical activity and sport of people with disabilities. According to the majority $( \pm 70 \%)$, awareness of a possibility of people with disabilities starting a sports activity was poor. Definitely lower percentages of students from both colleges considered it sufficient $(21.4 \%$ and $18.1 \%)$ or high $(18.5 \%$ and $10.9 \%)$. Its contribution to practical use of sport in rehabilitation process was considered significant only in the evaluation of every fifth of subject, while others considered it poor $(47.1 \%$ and $40.0 \%)$ or insufficient $(17.1 \%$ and $21.8 \%)$. Opinions on this subject expressed by male and female students from Bydgoszcz differed significantly in the statistical evaluation, which was presented in table 1 .

\begin{tabular}{|l|c|c|c|c|c|}
\hline category & male students & $\%$ & $\begin{array}{c}\text { female } \\
\text { students }\end{array}$ & $\%$ & total \\
\hline poor & 7 & 33.33 & 26 & 53.06 & 33 \\
\hline insufficient & 7 & 33.33 & 18 & 36.73 & 25 \\
\hline high & 7 & 33.33 & 5 & 10.20 & 12 \\
\hline total & 21 & 100 & 49 & 100 & 70 \\
\hline \multicolumn{7}{|c|}{ Chi-squared $=5.848485, \mathrm{p}=0.04937$} \\
\hline
\end{tabular}

Table I. Comparative characteristics presenting the evaluation of how the awareness of people with disabilities to the possibility to undertake a sports activity influences its realization in practice.

Tab. I. Charakterystyka porównawcza oceny wptywu świadomości osób niepetnosprawnych o możliwości podejmowania aktywności sportowej na praktyczna jej realizacje.

More female than male students noticed poor, and fewer noticed high level of the influence of awareness of people with disabilities on undertaking a sport or physical activity (Chi-squared $=5.848485, \mathrm{p}=0.04937)$. According to the majority of subjects $( \pm 71 \%)$, number of sports clubs and associations for people with disabilities was insufficient, while similar shares of the student groups considered them sufficient or failed to have an opinion on the matter. Students from Bydgoszcz in majority identified them with the Foundation of Active Rehabilitation (95.2\%), while students from Poznań with Polish Sport Association of People with Disabilities "Start" (90.4\%). Small percentages of subjects pointed to other, yet unidentified by them, organizations.

More than a half of subjects from both colleges $( \pm 65 \%)$ thought that the number of classes devoted to their familiarizing with the character of motor activity and sport of people with disabilities was sufficient, while the remaining subjects observed the necessity to increase it. Therefore, a similar share of the evaluation of sufficient and insufficient level of preparation to work in this area of rehabilitation was observed. Male students from Bydgoszcz, to a greater extent than female students, positively evaluated the degree of preparation to work with athletes with disabilities (Chi- 
squared $=11.228070, \mathrm{p}=0.00081)$, which was presented in table 2 .

\begin{tabular}{|l|c|c|c|c|c|}
\hline category & Male students & $\%$ & $\begin{array}{c}\text { Female } \\
\text { students }\end{array}$ & $\%$ & total \\
\hline insufficient & 5 & 23.81 & 33 & 67.35 & 38 \\
\hline sufficient & 16 & 76.19 & 16 & 32.65 & 32 \\
\hline total & 21 & 100 & 49 & 100 & 70 \\
\hline \multicolumn{6}{|c|}{ Chi-squared $=11.228070, \mathrm{p}=0.00081$} \\
\hline
\end{tabular}

Table II. Comparative characteristics presenting the evaluation of the degree of preparation of Collegium Medicum students for work connected with sports of people with disabilities.

Tab. II. Charakterystyka porównawcza oceny stopnia przygotowania studentów Collegium Medicum do pracy $w$ obszarze sportu osób niepetnosprawnych.

Consequently, a half of the subjects considered sport to be an inseparable element of rehabilitation possible to be realized by any patient. Similar percentages of the remaining subjects believed it to be a supplement to therapeutic process or its important element, yet not possible to be realized by all patients.

Opinions of the students from colleges included in the study concerning the possibility of athletes with disabilities competing in sports of healthy athletes differed significantly. Students from Bydgoszcz to a greater extent than students from Poznan noticed relevance of such rivalry and to a significantly lesser extent had no opinion on the subject (Chi-squared = $18.79256, p=0.00030$ ). Observed differences were presented in table 3 and figure 1 .

\begin{tabular}{|l|c|c|c|c|c|}
\hline category & $\begin{array}{c}\text { Collegium } \\
\text { Medicum }\end{array}$ & $\%$ & $\begin{array}{c}\text { Academy of } \\
\text { Physical } \\
\text { Education }\end{array}$ & $\%$ & total \\
\hline acceptable & 36 & 51.43 & 18 & 32.73 & 54 \\
\hline incomplete & 27 & 38.57 & 14 & 25.45 & 41 \\
\hline unacceptable & 4 & 5.71 & 6 & 10.91 & 10 \\
\hline no opinion & 3 & 4.29 & 17 & 30.91 & 20 \\
\hline total & 70 & 100 & 55 & 100 & 125 \\
\hline \multicolumn{7}{|c|}{ Chi-squared $=18.79256, \mathrm{p}=0.00030$} \\
\hline
\end{tabular}

Table III. Comparative characteristics presenting the evaluation of the possibility of athletes with disabilities competing in professional sport with healthy athletes.

Tab. III. Charakterystyka porównawcza oceny możliwości udziału niepetnosprawnych sportowców w sporcie kwalifikowanym osób petnosprawnych.

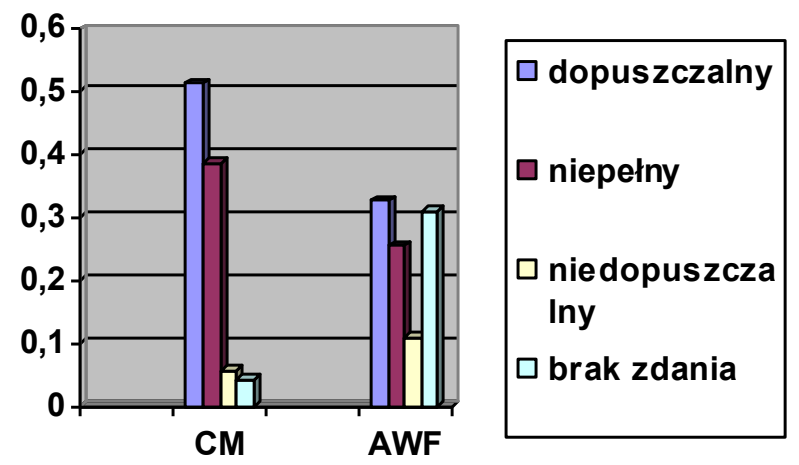

Figure 1. Graphic characteristics presenting the evaluation of the possibility of athletes with disabilities competing in professional sport with healthy athletes.
Ryc. 1. Graficzna charakterystyka oceny możliwości udziału niepetnosprawnych sportowców w sporcie kwalifikowanym osób petnosprawnych.

Opinions concerning the direction of the development of sports of people with disabilities were alike. Every fourth surveyed student supported the present concept of continuing the rehabilitation process or a form of social integration. The greatest percentages of students from both colleges $( \pm 36 \%)$ predicted its development towards professional sport and competing with healthy athletes $( \pm 15 \%)$. Hierarchy of sources of information concerning the possibility and need of people with disabilities practicing sport was similar in both groups of subjects. The majority pointed to physical therapy $( \pm 75 \%)$, another person with disability practicing sport $( \pm 70 \%)$ and the media $( \pm 40 \%)$. One fifth of subjects enumerated also a representative from a sports organization for people with disabilities and social campaigns, while a doctor was the least frequently mentioned by future physiotherapists $( \pm 10 \%)$. As main obstacles against undertaking a sports activity by people with disabilities future physiotherapists from both colleges pointed to architectural $( \pm 70 \%)$ and financial $( \pm 65 \%)$ barriers, as well as lack of complete data $(50.0 \%$ and $36.4 \%)$ and insufficient number of coaches and sports clubs $(31.4 \%$ and $34.6 \%)$. Similar percentages $( \pm 25 \%)$ enumerated reluctance towards undertaking sports activity or lack of sufficient awareness of its role in complex rehabilitation process.

\section{DISCUSSION:}

Previous analysis of data from realized studies allowed settling basic questions and forming several statements listed below.

1. Groups of students included in the study were of similar structure as far as sex, age, size of their home environment, rural in particular, were concerned; however, they differed concerning the curriculum of classes that students attended on the subject of sport of people with disabilities and their motor activity.

2. Studied determinants of professional awareness, attitudes and knowledge included in the study did not vary among men and women from colleges, while small differences, noted only in group from Bydgoszcz, concerned the influence of the awareness of people with disabilities on their practicing sports and the degree of preparation of graduates for work with people with disabilities.

3. Student groups included in the study differed as far as the possibility of athletes with disabilities competing with healthy athletes was concerned, which was the opinion of greater percentages of students from the medical school than the physical education college.

4. Students from the medical school associated physical activity of people with disabilities with the Foundation of Active Rehabilitation, while students from the physical education college associated it with Polish Sport Association of People with Disabilities "Start".

The above statements and the general picture of the results of the conducted study shows that hypotheses posed initially in majority were negatively verified. However, based on them expected differences and the level of preparation of the subject groups to work in sports of people with disabilities could not be directly concluded, particularly since the change in the name of specialization from "motor rehabilitation" to "physiotherapy" resulted in a new approach to educating specialists and a different understanding of the professional role 
of a therapist $[13,14]$. Therefore, prior to further conclusions, certain issues require more insight.

Similar headcount of male groups and the majority of female groups observed in the study confirms the existence of present in East-Central Europe process of feminization in medicine [15], and a similar structure of home environment of subjects, rural in particular, attests to the fact that both colleges are of local range and it is possible that specialization profile of a college offering physiotherapy specialization does not significantly influence sex structure and basic environmental conditioning of physical therapists.

Majority of students from both colleges included in the study got familiarized with the issue of sport of people with disabilities only during their college education, therefore, their commitment and knowledge did not exceed the material included in their curricula. A trace of the fact that interests and experience of relatively small shares of students from both colleges tend to differ is observed greater interest in Foundation of Active Rehabilitation volunteer work and knowledge about this organization among students from Bydgoszcz, with greater interest in coaching and knowledge about Polish Sport Association of People with Disabilities "Start" among students from Poznań. The above opinion is proven also by attitudes towards subjects' own motor activity, which allows achieving a higher level of physical fitness and prolonged professional activity, as well as utilising one's own experience while taking care of a patient $[16,17]$. Despite that fact, students from Bydgoszcz to a greater extent noticed the possibility of people with disabilities practicing sports, which is explained by a different realization of this specialization course in colleges included in the study, as well as by a more comprehensive understanding of the differences between the aims of sport of people with disabilities and healthy people by one of the subject groups [18]. Therefore, the view of Kowalik [19] concerning an insufficient preparation of rehabilitation therapists for work in sports of people with disabilities and the need to open a new specialization "adapted physical activity" stands confirmed. However, it is likely that the students of physical education college to a greater extent than students of medical school notice negative results of excessive motor activity, which in the case of professional sport is a common phenomenon, or perhaps they are more aware of dangers resulting from progressing professionalization of sport of people with disabilities.

Similar opinions of subjects are reflected in preferences of future profession. The majority plans starting their own rehabilitation practice, while one third plan to work in a hospital or a sanatorium. Alike expectations authors observed in previous studies [20], which could mean that a small share of people deciding on studying physiotherapy predicts their future profession to be connected with sports activity of people with disabilities. However, working in rehabilitation centres and on hospital wards enables contact with wide range of patients and is a perfect opportunity for propagation of motor activity and patients' activation also through sports. In such facilities a selection of the most beneficial motor activity or sports discipline should be suggested to a patient [18].It is the physical therapist that is of most help to people with disabilities in making most accurate decisions during their adaptation to new life situation and to solving problems connected with functioning in new environment [21]. Therefore, awareness and knowledge of physiotherapy students concerning the role of sport in lives of people with disabilities established during this study does not fill authors with optimism. Obtained results suggest that physiotherapy graduates from medical colleges, like their colleagues from physical education colleges, and perhaps students from other colleges, will promote sport of people with disabilities and support their physical activity. However, it seems that key role in this process is played by selfidentification with selected specialization and responsibility, which could be identified with a calling to the profession $[22,23]$.

\section{CONCLUSIONS:}

1. Similar headcount of male and female students from colleges included in the study and a similar structure of size of their home environment, rural in particular, prove that specialization profile of a college offering physiotherapy specialization does not significantly influence sex structure and basic environmental conditioning of physiotherapists.

2. Similar views of the studied male and female groups, which were not significantly influenced by differences in the curricula of their specialization courses as well as alike experience with sport of people with disabilities, prove a similar hierarchy of its importance in the complex rehabilitation process and point to the fact that specialization profile of a college may not influence students' commitment to activities beyond their curricula connected with sports and motor activity of people with disabilities.

3. Established differences in views of subjects may be a trace of the influence of specialization profile of a college or they may result from differences in realized curricula.

4. Results of this study allow a conclusion that awareness and knowledge of physiotherapy students concerning the position of sport and motor activity in the rehabilitation process are formed in colleges of different specialization profiles in a similar manner, therefore, the role of selfidentification of college applicants and a calling to the profession are important elements in this process.

\section{REFERENCES:}

1. Kikolski W. Sport niepełnosprawnych - wyczyn czy rehabilitacja? Kultura Fizyczna, 2000;7/8:28-30.

2. Czerwiak G, Krawczyńska J. Rola sportu i akceptacji własnej niepełnosprawności osób z dysfunkcją narządu ruchu. Akademia Świętokrzyska, Instytut Kształcenia Medycznego. Kielce; 2005.

3. Ładecki B. Przemówienie okolicznościowe, Międzynarodowe Seminarium „Sport w rehabilitacji niepełnosprawnych". w: Ślężyński J. red. Sport w rehabilitacji niepełnosprawnych. Polskie Stowarzyszenie Osób Niepełnosprawnych, Kraków; 1999.

4. Dega W, Milanowska K. Rehabilitacja medyczna. Warszawa; 1983.

5. Kosmol A, Morgulec-Adamowicz N, Molik B, Bębenek O, Krzak J, Gruszczyński K, Maniak-Iwaniszewska M, Rutkowska I, Skowroński W. Teoria i praktyka sportu niepełnosprawnych. Warszawa; 2008.

6. Tasiemski T. Sport w życiu osób z para- i tertraplegią. Medycyna Sportowa, 1999; 12: 101: 9-14.

7. Wybraniec-Lewicka B, Dromlewska D. Wybrane zagadnienia sportu osób niepełnosprawnych w Polsce. Medycyna aktywności fizycznej z elementami psychologii i pedagogiki, AWF Warszawa; 2010.

8. Prokopiuk M. Sport w rehabilitacji osób niepełnosprawnych. Postępy Rehabilitacji, 2001; 15 (2): 95-98. 
9. Łobocki M. Metody badań pedagogicznych. Warszawa; 1984.

10. Puślecki W. Metody badań pedagogicznych: obserwacja eksperyment - test-sondaż. Kalisz: Ośrodek Doskonalenia Nauczycieli; 1985.

11. Pilch T. Zasady badań pedagogicznych. Warszawa: Wydawnictwo „Żak”; 1985.

12. Juszczyk S. Statystyka dla pedagogów. Zarys wykładu. Wydawnictwo Adam Marszałek, Toruń; 2006.

13. Kwolek A. Rehabilitacja medyczna. t. I. Wydawnictwo Urban \& Partner; Wrocław: 2003.

14. Herbeger J. Psychospołeczne uwarunkowania przydatności magistrów rehabilitacji ruchowej do pracy zawodowej. Zeszyty Naukowe AWF Wrocław 1990; 51: 152-182.

15. Sokołowska M. Socjologia medycyny. Warszawa;1986.

16. Motylewski S, Pawlicka A, Gątkiewicz M, PoziomskaPiątkowska E. Aktywność fizyczna fizjoterapeutów. Kwartalnik Ortopedyczny 2008; 3: 306-313.

17. Kochanowicz B. Poziom sprawności fizycznej studentów kierunku fizjoterapii Akademii Medycznej w Gdańsku a ich opinia wobec różnych form aktywności ruchowej. Annales Academiae Medicae Gedanensis, 2007;37:53-62.

18. Beck J. Sport w rehabilitacji inwalidów. AWF Warszawa; 1977.

19. Kowalik S. Dylematy związane z przygotowaniem specjalistów wykorzystujących aktywność ruchowa w pracy $\mathrm{z}$ osobami niepełnosprawnymi. w: DłużewskaMartyniec W, (red), Kształcenie kadr dla potrzeb kultury fizycznej osób niepełnosprawnych. Wydawnictwo KKFOW, Poznań; 2003:13-28.

20. Lewandowski A, Saczuk D, Śmiglewska M. Justifications of the choice of the phisiotherapist occupation and chosen environmental conditions of youth from post secondary schools in the mazovian region. Medical and Biological Sciences, 2009;23/2:25-29

21. Żukowska Z. Pedagogiczne uwarunkowania efektywności leczniczej i aktywności sportowej a akceptowany system wartości. Ślężyński J. red. Sport w rehabilitacji niepełnosprawnych. Polskie Stowarzyszenie Osób Niepełnosprawnych, Kraków; 1999.

22. Pezdek K. Odpowiedzialność jako wartość w pracy fizjoterapeuty. Fizjoterapia 2010; 18/1: 72-76

23. Lewandowski A, Śmiglewska M, Smeja J.M. Właściwości indywidualne fizjoterapeuty $\mathrm{W}$ pomyślnej realizacji zawodu - na przykładzie wyników badań studentek kierunku fizjoterapii. Postępy Rehabilitacji, 2010;24/1:1319.

Address for correspondence:

Dr Andrzej Lewandowski

Uniwersytet Mikołaja Kopernika w Toruniu

Collegium Medicum im. Ludwika Rydygiera w Bydgoszczy

Katedra i Zakład Podstaw Kultury Fizycznej

tel./fax 52 585-36-12 / 585-11-19,

mail.kizpodskf@cm.umk.pl

Received: 26.02.2013

Acceoted for publication: 07.01.2014 